\title{
MODERATOR TO FUEL RATIO AND URANIUM FRACTION ANALYSIS OF SQUARE LATTICE MOLTEN SALT TRANSATOMIC POWER
}

\author{
Dion Bagus Nugraha B., Andang Widi Harto, Sihana \\ Department of Nuclear Engineering and Engineering Physics \\ Grafika 2 Streets Yogyakarta 55281 INDONESIA \\ E-mail: andangftn@yahoo.com \\ Diterima editor: 3 Agustus 2016 \\ Diperbaiki: 29 Desember 2016 \\ Disetujui untuk publikasi: 31 Januari 2017
}

\begin{abstract}
MODERATOR TO FUEL RATIO AND URANIUM FRACTION ANALYSIS OF SQUARE LATTICE MOLTEN SALT TRANSATOMIC POWER. Molten Salt Reactor Transatomic Power (MSR TAP) is a further development of the nuclear reactor Generation IV Reactor Molten Salt Reactor (MSR). MSR TAP generates clean electric power. It has a passive safety, resistance to proliferation, and low cost. MSR TAP can consume the rest of the nuclear fuel/spent nuclear fuel (SNF) of a commercial Light Water Reactor (LWR) fuel or use the main fuel, a salt solution $\mathrm{UF}_{4}-\mathrm{LiF}-\mathrm{BeF}_{2} \cdot \mathrm{MSR}$ TAP uses Zirconium Hydride material for the moderator. This research has a purpose to determine the optimal size of uranium mole fraction on fuel and moderator radius from core design in order to produce optimum enrichment with the value $1<\mathrm{k}_{\text {eff }}<1.0065$ using MCNP5 program. On the other hand, this research also aims to look for the optimum enrichment, which have inherent safety characteristics with $\alpha_{\text {Void }}<0$. Variations were made including the changes in the geometry of the moderator radius with a variation of $0.5 \mathrm{~cm}, 1 \mathrm{~cm}, 1.5 \mathrm{~cm}, 2 \mathrm{~cm}, 2.5 \mathrm{~cm}, 3 \mathrm{~cm}, 3.5 \mathrm{~cm}, 4 \mathrm{~cm}$, and $4.5 \mathrm{~cm}$; and the changes in the fuel uranium molar UF4 - LiF - BeF2 with molar variation of $15 \%, 20 \%, 25 \%$ and $30 \%$. The geometry of Transatomic Power (MSR TAP) of companies Transatomic Power Corporation was used. The results show that the optimum variation is the salt solution $\mathrm{UF}_{4}-\mathrm{LiF}-\mathrm{BeF}_{2}$ with $25 \%$ uranium mole fraction, $2.6 \%$ enrichment and moderator radius of $1.5 \mathrm{~cm}$. The optimum variation gives the $\mathrm{k}_{\text {eff }}$ value of $1.00124 \pm$ 0.00078 . The optimum value of reactivity void coefficient is -0.0684 . It indicates an inherently safe design.

Keywords : Molten Salt Reactor Transatomic Power, MCNP5, Uranium Fuel Mole Fraction, Optimum Variation, Moderator, Inherent Safety.
\end{abstract}

\section{ABSTRAK}

ANALISIS FRAKSI URANIUM DAN RASIO MODERATOR - BAHAN BAKAR PADA SQUARE LATTICED MOLTEN SALT TRANSATOMIC POWER. Molten Salt Reactor Transatomic Power (MSR TAP) merupakan reaktor nuklir pengembangan lebih lanjut dari Reaktor Generasi IV Molten Salt Reactor (MSR). Reaktor MSR TAP ini menghasilkan daya listrik yang bersih, memiliki keselamatan pasif, mempunyai resistensi terhadap proliferasi, dan memiliki biaya yang rendah. Reaktor ini dapat mengkonsumsi bahan bakar nuklir sisa/spent nuclear fuel (SNF) dari penggunaan bahan bakar Light Water Reactor (LWR) yang komersial atau menggunakan bahan bakar utama yaitu larutan garam $\mathrm{UF}_{4}-$ $\mathrm{LiF}-\mathrm{BeF}_{2}$. Moderator yang digunakan pada MSR TAP ini adalah moderator berbahan Zirconium Hydride. Penelitian ini bertujuan untuk menentukan ukuran perbandingan nilai fraski mol uranium dan jari-jari moderator yang optimal dari dari desain teras Reaktor MSR TAP agar dihasilkan pengayaan yang optimum dengan nilai $1<k_{\text {eff }}<1,0065$ menggunakan program MCNP5. Selain itu penelitian ini juga bertujuan mecari pengayaan optimum yang mempunyai sifat keselamatan melekat dengan $\boldsymbol{\alpha}_{\text {Void }}<$ 0. Variasi yang dilakukan meliputi perubahan geometri jari-jari moderator dengan variasi $0,5 \mathrm{~cm}, 1 \mathrm{~cm}$, $1,5 \mathrm{~cm}, 2 \mathrm{~cm}, 2,5 \mathrm{~cm}, 3 \mathrm{~cm}, 3,5 \mathrm{~cm}, 4 \mathrm{~cm}$, dan $4,5 \mathrm{~cm}$; dan perubahan molar uranium pada bahan bakar $\mathrm{UF}_{4}-\mathrm{LiF}-\mathrm{BeF}_{2}$ dengan variasi persen molar 15\%, 20\%, 25\%, dan 30\%. Geometri reaktor yang digunakan dalam silmulasi adalah MSR TAP dari perusahaan Transatomic Power Corporation. Hasil penelitian menunjukkan variasi optimum perbandingan moderator bahan dan fraksi mol bahan bakar larutan garam $\mathrm{UF}_{4}-\mathrm{LiF}-\mathrm{BeF}_{2}$ pada fraksi mol uranium bahan bakar pada variasi molar uranium $25 \%$ dengan pengayaan $2,6 \%$ dan jari-jari moderator $1,5 \mathrm{~cm}$, dengan nilai $k_{\text {eff }} 1,00124 \pm 0,00078$. Koefisien reaktivitas void yang didapatkan dari variasi optimum tersebut adalah -0,0684 yang menandakan bahwa desain ini telah memenuhi syarat keselamatan melekat.

Kata kunci : Molten Salt Reactor Transatomic Power, MCNP5, Fraksi mol uranium, Variasi optimum, Moderator, Keselamatan melekat. 


\section{INTRODUCTION}

The rate of world energy consumption continues to rise. The rate of primary energy consumption (utilization of energy resources) of the world's total in 2004 is amounted to be approximately $15 \mathrm{TW}(1 \mathrm{TW}=1012$ Watt $)$ with the uncertainty of the data by $10 \%$. This consumption rate is equivalent to $470 \mathrm{EJ}$ per year $(1 \mathrm{EJ}=1018$ Joule) [1]. This problem is caused by three primary factors, which are, (1) the increase in energy demand due to the population growth and the demands for better living standards; (2) a very large dependence on conventional energy resources (fossil), as coal, oil and gas; and (3) the limited availability of alternative conventional energy resources [1]. The importance of efforts to develop alternative energy sources such as nuclear and renewable energy resources are required.

Recently, the nuclear reactor technology has reached maturity in the form of Generation III+ nuclear reactor design. However, the problem of long term radioactive waste and the need to increase the safety and competitiveness of nuclear reactor lead to develope the next generation of nuclear reactor, i.e. Generation IV. This is a challenge because the Generation IV nuclear reactor should meet the high standards in nuclear safety, effective waste management and proliferation resistance and competitive cost [2].

Transatomic Molten Salt Reactor Power (MSR TAP) is designed by Transatomic Power Corporation. The MSR TAP uses low-enriched uranium of $1.8 \%$ U-235 and ${ }^{7} \mathrm{LiF}_{-}-\mathrm{BeF}_{2}-\mathrm{UF}_{2}$ solution without thorium. It can reduce the proliferation risk [3].

The objective of this work is to optimize moderator fuel ratio and mole fraction of the uranium in the fuel towards Molten Salt Reactor Transatomic Power (MSR TAP) criticality with square lattice. In reality, although the technical document of Transatomic Technical White Paper states that the enrichment used is $1.8 \%$, however, it does not provide the technical data of the reactor design. Since, there is no data available in the literature, thus, this study is intended to determine the optimal size ratio of uranium mole fraction and optimal moderator radius from MSR TAP design in order to produce optimum enrichment. This work is expected to contribute on the development of MSR design, especially MSR TAP design as future breeder reactors.

\section{THEORY}

Molten Salt Reactor Transatomic Power (MSR TAP) is still in the stage of design and test of Transatomic Power Corporation. This reactor is a further development of Generation IV nuclear reactor. According to the claims of this company, reactor can use spent fuel of Light Water Reactor (LWR) or main fuel to achieve high actinide burnup of $96 \%$ and produce 75 times higher electrical power per ton of uranium as compared to LWR. Characteristic projections of MSR TAP reactor parameters are presented in Table 1.

Table 1. Parameters of MSR TAP [3].

\begin{tabular}{ll}
\hline Parameter Type & Parameter Value \\
\hline Reactor Type & Molten Salt Fueled Reactor \\
Fuel Type & Uranium or Spent Nuclear Fuel \\
Fuel Salt & $\mathrm{LiF}_{-} \mathrm{BeF}_{2}$ \\
Moderator & Zirconium Hydride $\left(\mathrm{ZrH}_{4}\right)$ \\
Neutron Spectrum & Thermal Neutron \\
Thermal Capacity & $1250 \mathrm{MWth}$ \\
Gross Electricity Production Capacity & $550 \mathrm{MWe}$ \\
Net Electricity Production Capacity & $520 \mathrm{MWe}$ \\
Outlet Temperature & $650^{\circ} \mathrm{C}$ \\
Gross Thermal Efficiency & $44 \%$ using steam cycle with reheat \\
Fuel Efficiency & 75 times higher per MW than LWR \\
Long-lived Actinide Waste & Up to $96 \%$ less per MW than LWR \\
Station Blackout Safety & Walkaway safe without outside intervention \\
Overnight Cost & $\$ 2$ billion \\
Mode of Operation & Typically for base load; May be used for load following \\
Designers & Transatomic Power Corporation \\
\hline
\end{tabular}


MSR TAP, as well as current commercial reactors, uses a thermal neutron spectrum. Thermal neutron spectrum is used to avoid greater damage to the structure of the reactor material as in fast neutron spectrum nuclear reactor [3].

Fission reaction is a nuclear reaction or radioactive decay process, when neutron absorbed then leads to the possibility chain reaction. Material that is capable undergoing fission reaction is called fissile material, such as uranium-235, plutonium-239, uranium-233 and others. Every fissile material bombarded by neutrons splits in two smaller parts, produce two or three neutrons and releases energy. The reaction can be expressed in Equation (1) as follows.

$$
{ }_{92}^{235} U+{ }_{0}^{1} n \stackrel{\text { Fission Reaction }}{\longrightarrow}{ }_{54}^{140} X e+{ }_{38}^{94} S r+v{ }_{0}^{1} n+\text { Energy }
$$

Neutron multiplication factor is defined as the ratio between the number of fission reactions that occur in a generation with the number of fission reactions in the previous generations. In conditions of the reactor that are infinite (very large size), assuming the neutrons will not be out of the reactor, to measure the ratio of the number of neutrons formulated as in Equation (2) [5].

$$
k_{\infty}=\frac{\text { the number of fission reactions that occur in a generation }}{\text { the number of fission reactions in previous generations }}
$$

Neutron multiplication factor in an infinite medium can be formulated as in Equation (3).

$$
k_{\infty}=\eta \cdot f \cdot p \cdot \varepsilon
$$

with :

$\eta \quad=$ reproduction factor;

$f \quad=$ thermal utilization factor;

$p \quad=$ resonance escape probability;

$\varepsilon \quad=$ fast fission factor,

For a finite medium (the size of the reactor can be measured), the neutron multiplication factor can be formulated as in Equation (4).

$$
\begin{aligned}
& k_{\text {eff }}=\frac{\text { the number of fission reactions that occur in a generation }}{\text { the number of neutrons are absorbed in the previous generation }+} \\
& \text { number of neutrons leaking in the previous generation }
\end{aligned}
$$

Neutron multiplication factor in a finite medium can also be formulated in Equation (5) [6].

with :

$$
k_{e f f}=k \cdot \mathfrak{Q}_{f} \cdot \mathfrak{Q}_{t}=\eta \cdot f \cdot p \cdot \varepsilon \cdot \mathfrak{Q}_{f} \cdot \mathfrak{Q}_{t}
$$

$\mathfrak{I}_{f}=$ number of fast neutrons that do not leak from reactor divided by number of fast neutrons produced by all fissions;

$\mathfrak{Q}_{t} \quad=$ number of thermal neutrons that do not leak from reactor divided by number of neutrons that reach thermal energies.

Fraction changes in system of the critical state into a supercritical or sub-critical defined as reactivity $(\rho)$ [4]. Reactivity defined in Equation (6).

$$
\rho \cong \frac{k-1}{k}
$$

where $\mathrm{k}$ is the neutron multiplication factor.

The dominant effect on the reactivity of the reactor, which uses a liquid fuel, is a moderator density changes that also serves as a coolant, both due to thermal expansion and the production void. In principle, this effect is caused by loss of moderation that accompanied by moderator density reduction results in increasing of resonance absorption. In the case of the MSR reactor, 
molten salt fuel carrier also acts as coolant. Void in molten salts can occur due to the operation of reactor where the temperature is close to the saturation temperature, cause boiling and bubble formation in the reactor core. However, the possibility of emergence of void by this mechanism is small due to the high boiling point of molten salt [4]. Void in the MSR also occurs due to the formation of fission products in the gas phase. Besides, the formation of voids in the molten salt also led to reduction of fuel density [5].

Void reactivity coefficient can be formulated in Equation (7) [5].

$$
\alpha_{v o i d}=\alpha_{\vartheta}=\frac{1}{k} \frac{d k}{d \vartheta}
$$

Increasing fuel temperature results in the increase of void in MSR reactor fuel. The higher the temperature of the fuel means the higher of void in the fuel or the lower the density of fuel. The effects of moderator with the fuel ratio is illustrated in Figure 1 [7].

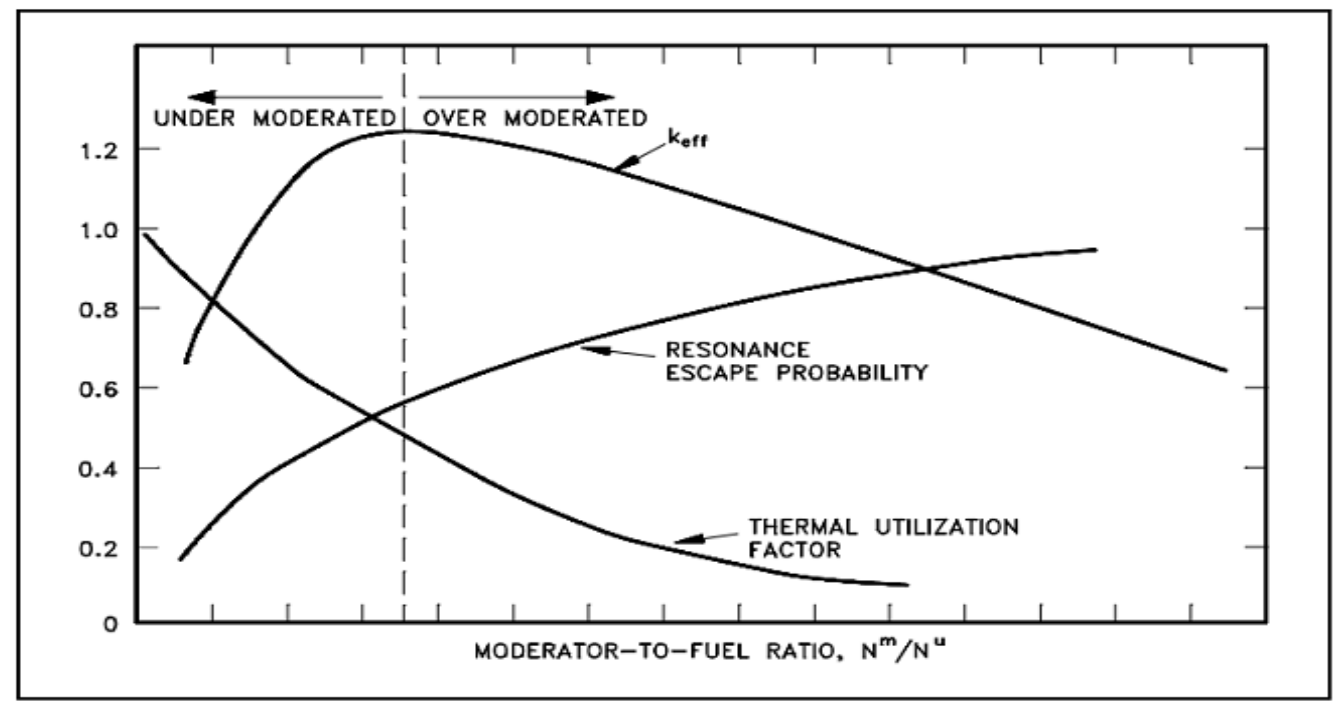

Figure 1. The ratio of moderator to fuel [7]

\section{METHODOLOGY}

This work is started by gathering literatures related to the design and characteristics of the Molten Salt Reactor Transatomic Power (MSR TAP). The literature documents obtained from technical publications of MSR TAP that is available on the Transatomic Power Corporation website, as well as from the articles and journals.

The MCNP (Monte Carlo N-Particle) were used to find the $k_{\text {eff }}$ value by applying the probabilistic methods [8,9]. Microsoft Excel 2010 was used to display data into graphs to obtain void reactivity coefficient values.

Figure 2 and Figure 3 show MSR TAP reactor modeling using MCNP 5 Visual Editor, the yellow, red and green respectively describe fuel salt, zirconium hydride moderator and graphite reflector. Variations for moderator radius were performed from $0.5 \mathrm{~cm}$ up to $4.5 \mathrm{~cm}$ with a $0.5 \mathrm{~cm}$ margin (9 variables) of each variation of the mole fraction of U-235 on fuel solution UF4 - LiF BeF2 $(15 \%, 20 \%, 25 \%, 30 \%)$. This variation is then followed with a fixed-size input variable geometry design and material reactor core fuel, moderator, cladding, control rod, and a plenum on MCNP program.

Variations that meet the requirements of $\mathrm{k}_{\text {eff }}$ was taken to determine the optimum value. The keff required in the range $1<\mathrm{k}_{\text {eff }}<1.0065$. It corresponds to the fuel reactivity value that does not exceed the $\beta$ value for the $\mathrm{U}-235$ which is 0.0065 [10]. 
The optimum design will meet the inherent safety qualification when the fuel changes the material composition for their void. In order to get the void reactivity coefficient, we assumed a reduction in the density of the fuel, or in other word reduced density becomes void. There are several variations made in density reduction such as $0 \%, 1 \%, 2 \%, 3 \%, 4 \%, 5 \%, 6 \%, 7 \%, 8 \%, 9 \%$ and $10 \%$

The values of $\mathrm{k}_{\mathrm{eff}}$ are obtained from the MCNP5 simulation then used to calculate void reactivity. The value of void reactivity will be projected into a void function graph. If the reactivity coefficient is negative means the design meets the inherent safety.

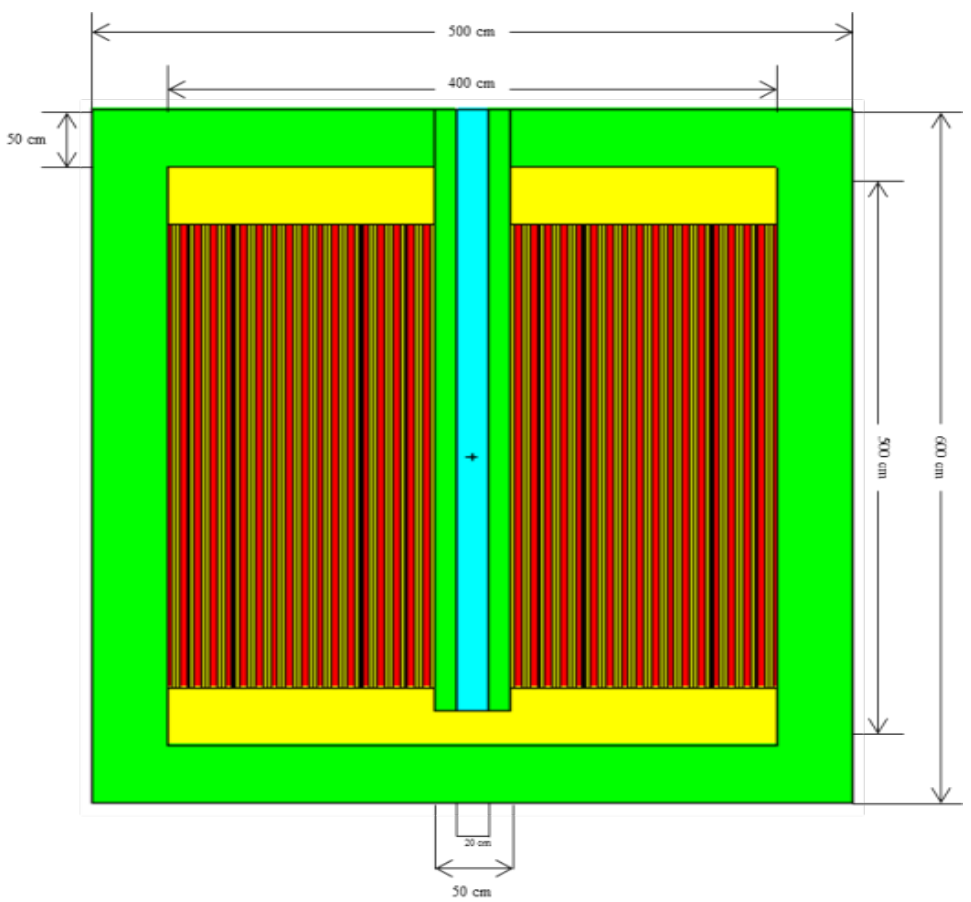

Figure 2. 2D Model MSR TAP longitudinal section Visual Editor display

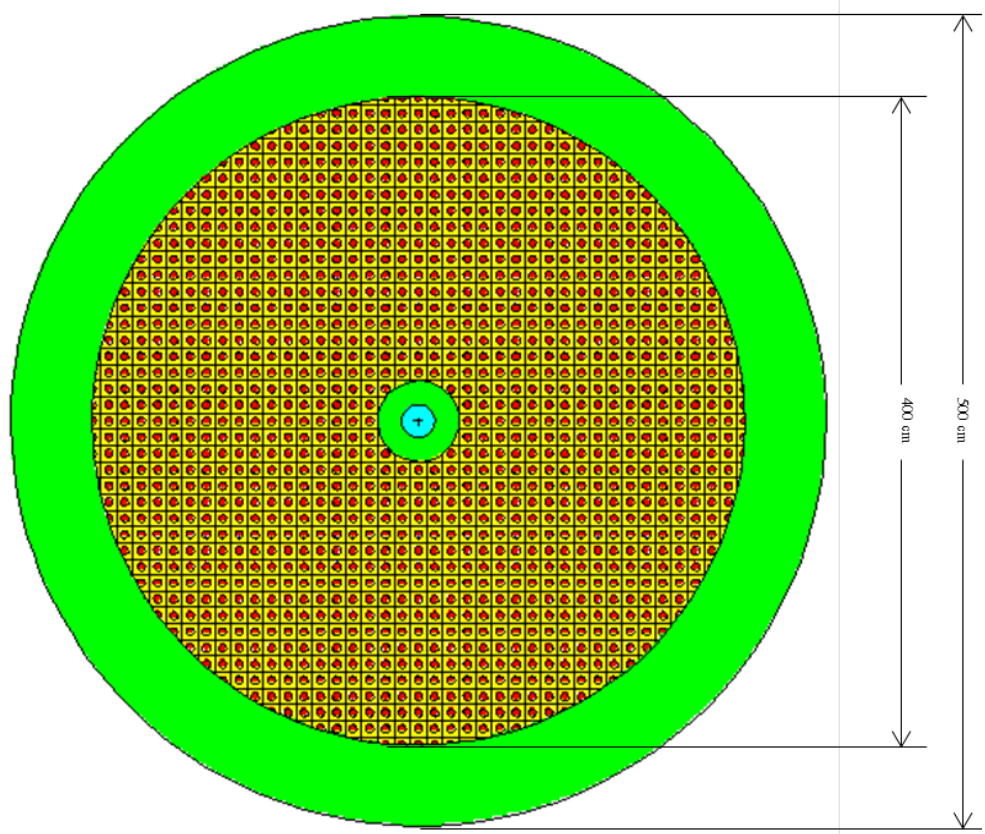

Figure 3. 2D Model MSR TAP cross section Visual Editor display 


\section{RESULTS AND ANALYSIS}

The results of the keff value as a function of moderator radius for several U-235 enrichment level using the fuel salt solution UF4 - LiF - BeF2 with several salt composition are shown in Figure 4, Figure 5, Figure 6 and Figure 7.

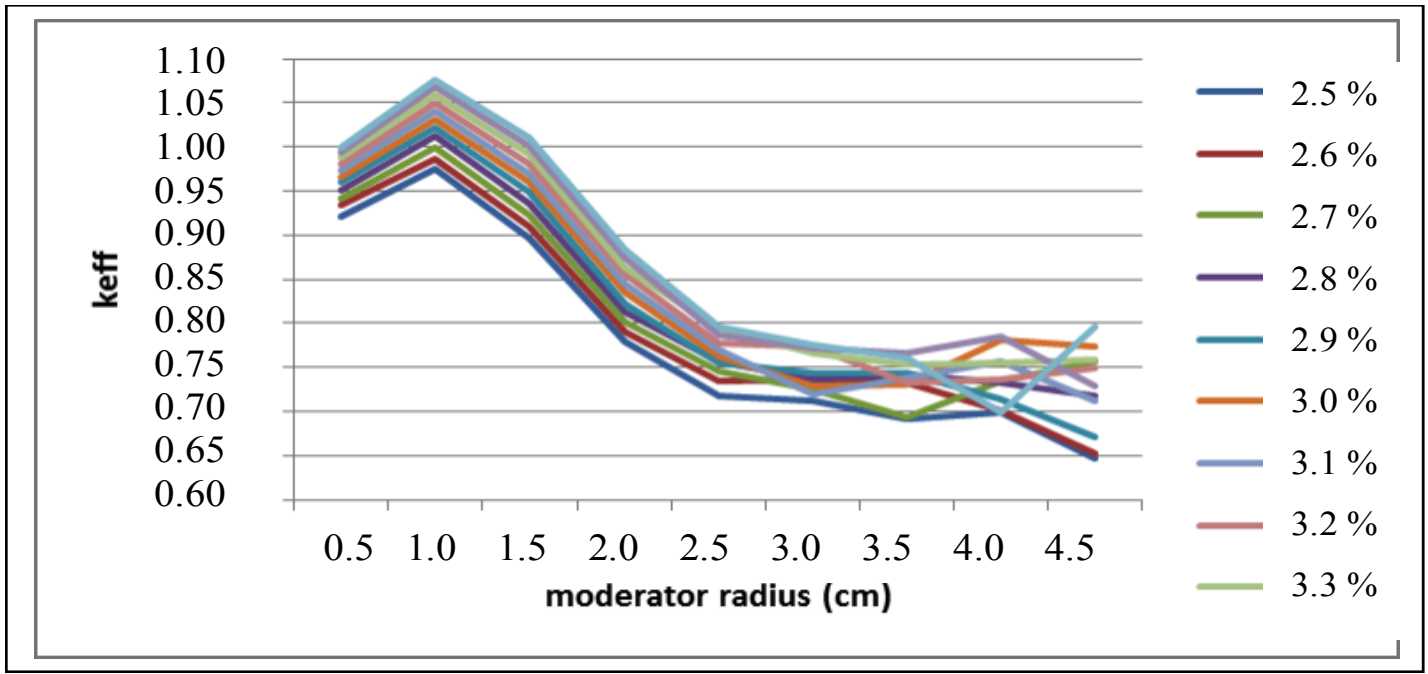

Figure 4. The keff versus moderator radius for fuel salt with the mole fraction of UF4 - LiF - BeF2 respectively at the value of $15 \%-63.75 \%-21.25 \%$

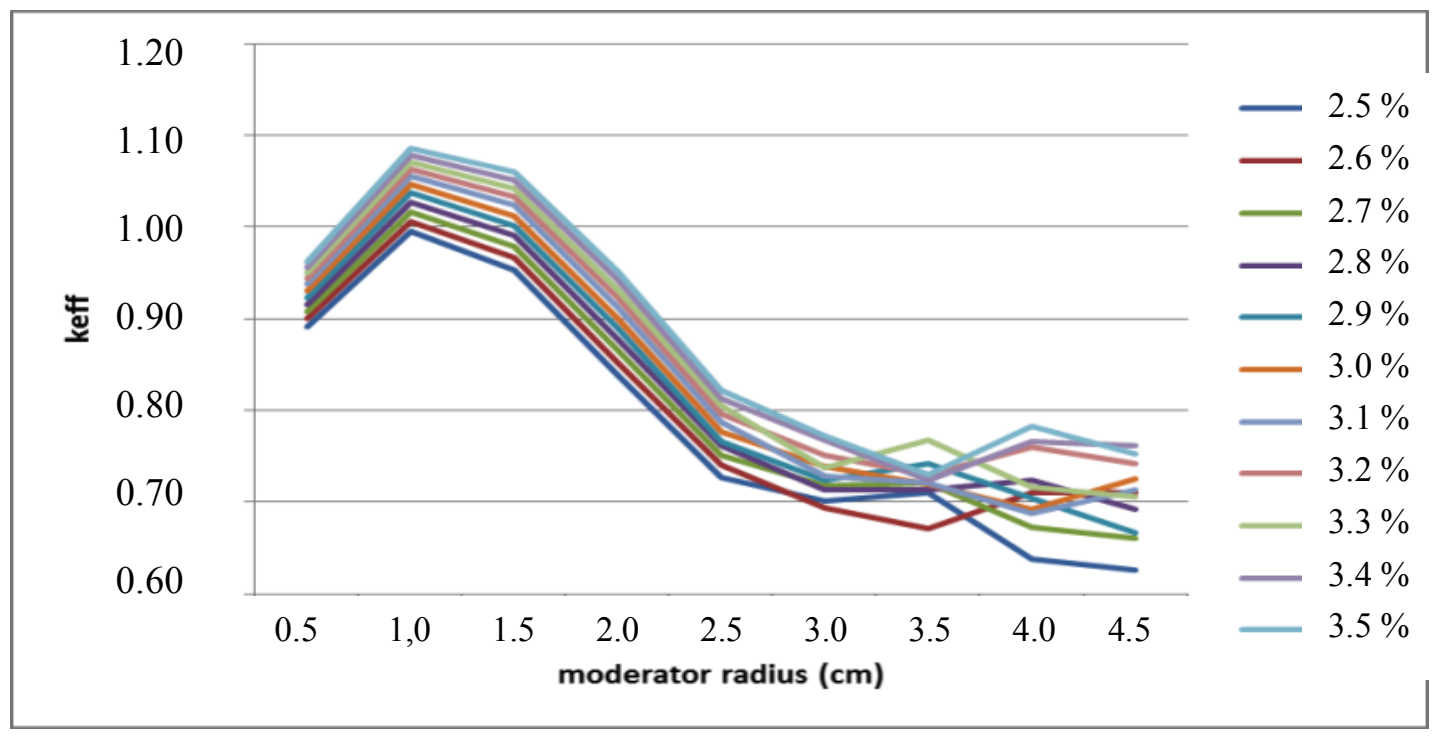

Figure 5. The keff versus moderator radius for fuel salt with the mole fraction of UF4 - LiF - BeF2 respectively at the value of $20 \%-60.00 \%-20.00 \%$ 


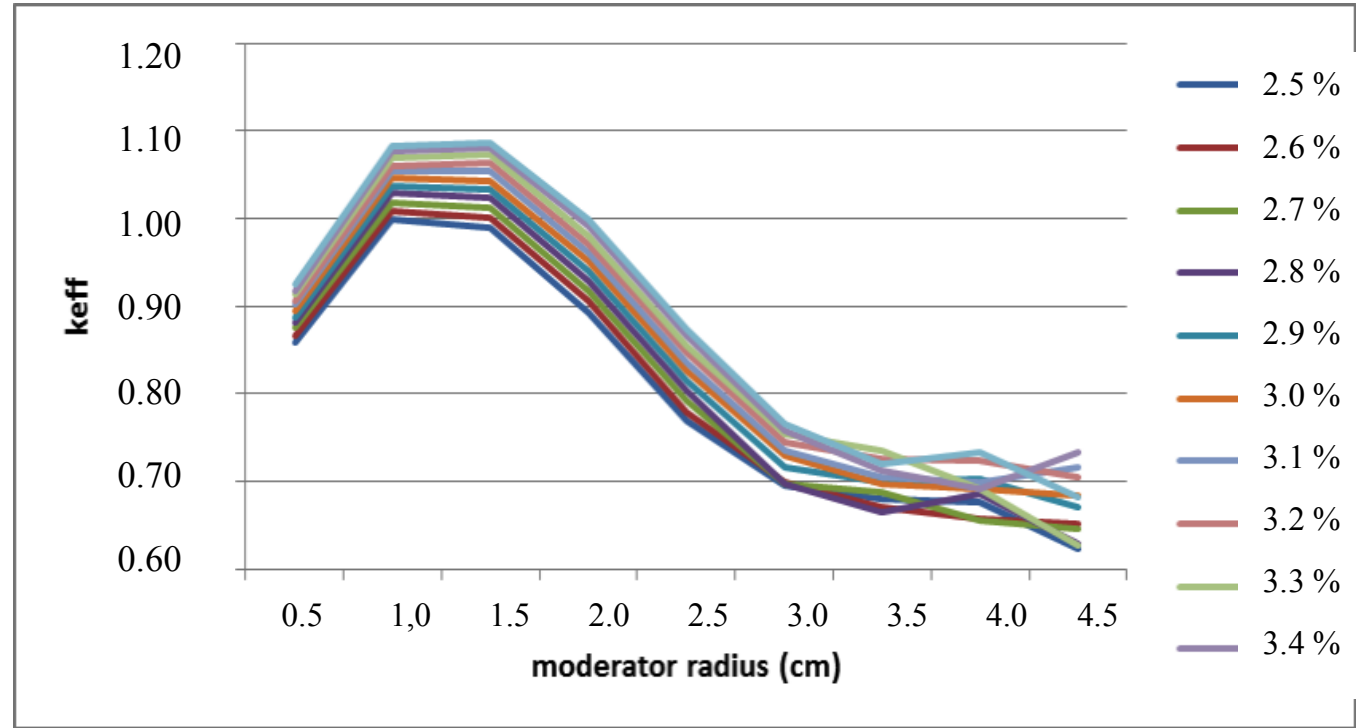

Figure 6. The keff versus moderator radius for fuel salt with the mole fraction of UF4 - LiF - BeF2 respectively at the value of $25 \%-56.25 \%-18.75 \%$

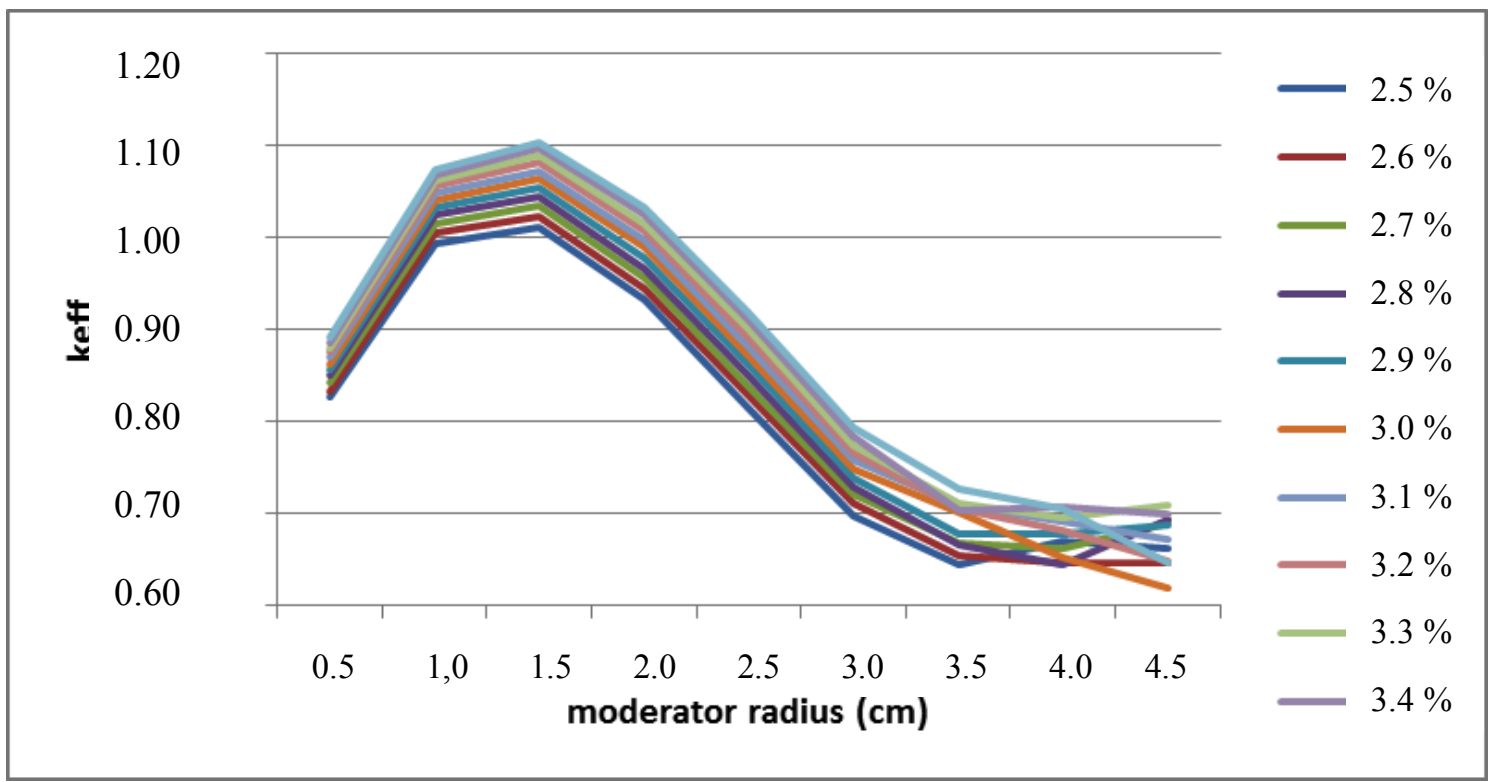

Figure 7. The keff versus moderator radius for fuel salt with the mole fraction of of UF4 - LiF - BeF2 respectively at the value of $30 \%-52.50 \%-17.50 \%$

The legend of these four figures state the U-235 enrichment level. Figure 4, Figure 5, Figure 6 and Figure 7 suggest that there are several optimum moderator radius that give maximum value of criticality. The optimum moderator radius for fuel salt with $15 \%$ mole of $U$ is $1 \mathrm{~cm}$. The optimum radius tend to shift to higher value as the mole fraction of the fuel increase. The phenomena correspond to the fuel to moderator ratio behavior. The smaller moderator radius means the smaller the amount of moderator or the larger the amount of fuel. The more fuel mean more fission reaction occurs and thus more fast neutron will be produced. On the other hand, the more fuel means less moderator. This will reduce the chance of the fast neutron to be thermalized, thus the less of the chance of the fission reaction to occur. These two effects compete, leading the maximum chance of the fission reaction to produce neutron. This maximum chance is related to the optimum fuel to moderator ratio, i.e. optimum moderator radius. 
MSR Reactor, contrary to LWR reactor, uses a liquid fuel and solid moderator. Therefore, as temperature rises, fuel will expand. This cause the operating conditions of MSR are on over moderated conditions. In this condition, the expansion of fuel will increase $\mathrm{Nm} / \mathrm{Nu}$, since the amount of the fuel to the moderator ratio increasing due to reduction of the fuel nuclides in the core. As a result, the resonance escape probability increases, while the thermal utilization factor decreases. This phenomenon causes a decreasing of keff value and give the effect of negative reactivity.

From manual calculation of $\mathrm{Nm} / \mathrm{Nu}$, the volume ratio of moderator to fuel volume changes in the amount of salt on the radius of moderator shown in Table 2. Table 3 shows the optimum variations of keff value, which are in the stable condition range of $1<\mathrm{keff}<1.0065$

Table 2. Value of $\mathrm{Nm}$ / Nu Comparison against Moderator Radius Variations

\begin{tabular}{|c|c|c|c|c|c|}
\hline $\begin{array}{l}\text { Moderator } \\
\text { radius }(\mathbf{c m})\end{array}$ & $\begin{array}{c}\text { Moderator } \\
\text { volume (cc) }\left(\mathbf{N}_{\mathrm{m}}\right)\end{array}$ & $\begin{array}{c}\text { Cladding } \\
\text { volume (cc) }\end{array}$ & $\begin{array}{c}\text { Number } \\
\text { of } \\
\text { moderator }\end{array}$ & $\begin{array}{c}\text { Fuel } \\
\text { Volume (cc) } \\
\left(\mathbf{N}_{\mathrm{u}}\right)\end{array}$ & $\mathbf{N}_{\mathrm{m}} / \mathbf{N}_{\mathrm{u}}$ comparison \\
\hline 0.5 & 314.15926 & 65.9734446 & 1220 & 49801720 & $6.3082 \mathrm{E}-06$ \\
\hline 1 & 1256.63704 & 128.8052966 & 1220 & 48575242 & $2.58699 \mathrm{E}-05$ \\
\hline 1.5 & 2827.43334 & 191.6371486 & 1220 & 46582216 & $6.06977 \mathrm{E}-05$ \\
\hline 2 & 5026.54816 & 254.4690006 & 1220 & 43822641 & 0.000114702 \\
\hline 2.5 & 7853.98150 & 317.3008526 & 1220 & 40296517 & 0.000194905 \\
\hline 3 & 11309.73336 & 380.1327046 & 1220 & 36003845 & 0.000314126 \\
\hline 3.5 & 15393.80374 & 442.9645566 & 1220 & 30944624 & 0.000497463 \\
\hline 4 & 20106.19264 & 505.7964086 & 1220 & 25118855 & 0.000800442 \\
\hline 4.5 & 25446.90006 & 568.6282606 & 1220 & 18526537 & 0.001373538 \\
\hline
\end{tabular}

Table 3. keff Value qualified in the range of $1<\mathrm{kef}<1.0065$

\begin{tabular}{cccc}
\hline $\begin{array}{c}\text { Comparison of Molar } \mathbf{U F} \\
\mathbf{B e F}_{\mathbf{2}}-\mathbf{L i F}-\end{array}$ & Enrichment & $\begin{array}{c}\text { Moderator } \\
\text { radius (cm) }\end{array}$ & $\mathbf{k}_{\text {eff }}$ \\
\hline $15 \%: 63.75 \%: 21.25 \%$ & $3,4 \%$ & 1,5 & $1.00223 \pm 0.00064$ \\
$20 \%: 60.00 \%: 20.00 \%$ & 2,9 & 1,5 & $1.00183 \pm 0.00071$ \\
$25 \%: 56.25 \%: 18.75 \%$ & 2,6 & 1,5 & $1.00124 \pm 0.00078$ \\
$30 \%: 52.50 \%: 17.50 \%$ & $3,2 \%$ & 2 & $1.00603 \pm 0.00061$ \\
\hline
\end{tabular}

The optimum design is considered to be inherently safe if the void reactivity coeficient is negative. Void reactivity coefficient is defined as the change in reactivity per percent change of void volume. In the liquid-fueled reactor such as MSR reactor, void occurs due to the presence of gaseous fission products in the fuel, for example, Xe-133. The occurrence of voids is due to the low possibility of fuel to boil. This phenomenon caused by the high boiling point of the salt.

The existence of voids in the fuel will reduce the fuel density. The void in MSR mainly occurs due to the generation of gaseous fission products. The void effect calculations were conducted with a void range of $0-10 \%$. The choice range is based on the argumen that higher voiding degree has small probability to occurs in MSR due to the high boiling point of the fuel salt..

To determine the optimum design of moderator-fuel ratio and the mole fraction of the criticality of uranium enrichment can be done by choosing the most effective value in reaching criticality. The optimum design moderator-fuel ratio and the mole fraction of the criticality of $2.6 \%$ enrichment on $25 \%$ uranium mole fraction is a moderator with radius of $1.5 \mathrm{~cm}$.

Salt density reduction as a function of void at $25 \%$ at mole fraction of uranium is shown in Table 4 
Table 4. Fuel salt density on variations void

\begin{tabular}{cc}
\hline & Density $\left(\mathrm{g} / \mathrm{cm}^{3}\right)$ \\
Void $(\%)$ & $\mathrm{UF}_{4}-\mathrm{LiF}-\mathrm{BeF}_{2} 25 \%: 56.25 \%: 18.75 \%$ \\
\hline $0 \%$ & 3.01083 \\
$1 \%$ & 2.98073 \\
$2 \%$ & 2.95062 \\
$3 \%$ & 2.92051 \\
$4 \%$ & 2.89040 \\
$5 \%$ & 2.86029 \\
$6 \%$ & 2.83018 \\
$7 \%$ & 2.80008 \\
$8 \%$ & 2.76997 \\
$9 \%$ & 2.73986 \\
$10 \%$ & 2.70975 \\
\hline
\end{tabular}

Void reactivity effect is calculated to the enrichment of $2.6 \%$ on mole fraction of uranium to $25 \%$ with moderator radius of $1.5 \mathrm{~cm}$ to obtain whether it qualifies optimum inherent safety design. The test results of void reactivity MSR TAP is shown in Figure 8.

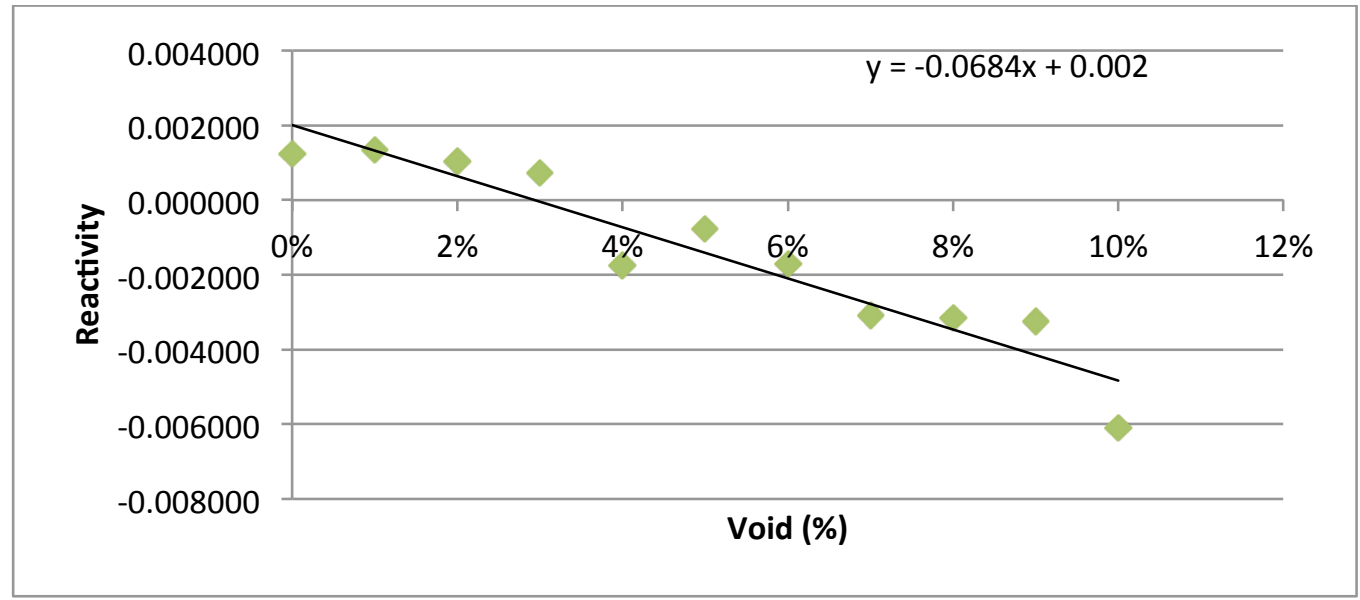

Figure 8 . Reactivity versus percent of void for fuel salt with the composition of UF4 - LiF $-\mathrm{BeF}=2$ $25 \%-56.25 \%-18.75 \%$ with $2.6 \%$ of U-235 enrichment and moderator radius of $1.5 \mathrm{~cm}$

Figure 8 shows that improvement of void is constantly accompanied by decreasing in reactivity, which means negative void reactivity. The pattern of reactivity on graph tends to decrease; however it is not linear. Thus, the reactivity coefficient value approach is more appropriate using linear regression line. The void coefficient of reactivity obtained at the gradient on the linear regression line.

From the zone of moderation point of view, it is appropriate to employ the moderator radius of 1.5 in over moderated zone. In other words, this variation is eligible the negative void coefficient of reactivity. Thus, the value of $\alpha$ void variation molar UF4 - LiF - BeF2 25\%: 56.25\%: $18.75 \%$ with $2.6 \%$ enrichment and moderator radius of $1.5 \mathrm{~cm}$ is -0.0684 . Sice $\alpha$ void is negative, then this design is considered as inherent safety design.

\section{CONCLUSION}

Based on the analysis optimization, moderator-fuel ratio and the mole fraction of the criticality performed on MSR TAP obtained optimum variation on fuel mole fraction of saline 
solution UF4 - LiF - BeF2 25\%: 56.25\%: $18.75 \%$ with 2.6\% enrichment and moderator radius of $1.5 \mathrm{~cm}$, with a value of $1.00124 \pm 0.00078 \mathrm{keff}$. Void reactivity coefficient are -0.0684 indicating that this design has inherent safety qualification.

\section{REFERENCES}

1. Harto, A.W., Kusnanto. “Diktat Teknologi Reaktor Maju”. Program Studi Teknik Nuklir Jurusan Teknik Fisika Universitas Gadjah Mada, Yogyakarta. 2013

2. Suwoto dan Zuhair, "Studi dan Observasi Awal Kebutuhan Data Nuklir untuk Reaktor Generasi IV (Gen-IV)", Pusat Teknologi Reaktor dan Keselamatan Nuklir BATAN, Indonesia, 2012

3. Anonim. "Transatomic Technical White Paper V 1.0.3". Transatomic Power Corporation. March 2016.

4. Benes, O., Cabet, C., Delpech, S., Hosnedl, P., Ignatiev, P., Konings, R., Lecarpentier, D., Matal, O., Merle-Lucotte, E., Renault, C., Uhlir, J., 2009, Aseessment of Liquid salts for Innovative Application ALISIA Deliverable (D-50), Review Report on Liquid Salts for Various Applications

5. James J. Duderstadt dan Louis J. Hamilton. Nuclear Reactor Analysis. John Wiley And Sons, Inc., New York, 1976.

6. J.R. Lamarsh. Introduction to Nuclear Reactor Theory. Adison-Wesley Publishing Company. Massachusetts. 1966.

7. Nuclear Physics and Reactor Theory. DOE Fundamentals Handbook, DOE-HDBK-1019/293, Volume 2 of 2, U.S. Department of Energy, Washington, 1993.

8. LANL, A General Monte Carlo N-Particle (MCNP) Transport Code, 2016, http://www.lanl,gov/vhosts/menp.lanl.gov/reference.shtml\#mcnp6 refs

9. X-5 Monte Carlo Team, MCNP - A General Monte Carlo N-Particle Transport Code, 2000, http://www.nucleonica.net/wiki/images/8/89/mcnpvoli.pdf

10. David L. Hetric. Dynamics of Nuclear Reactors. The University of Chicago Press, Chicago, 1971. 